\title{
Code Switching and Code Mixing by The Government of Bali
}

\section{Ni Putu Ayu Yuni Sugiantari \\ Magister Linguistic, Postgraduated Program, Universitas Warmadewa, Denpasar-Bali, Indonesia}

*yunibaratha80@yahoo.com

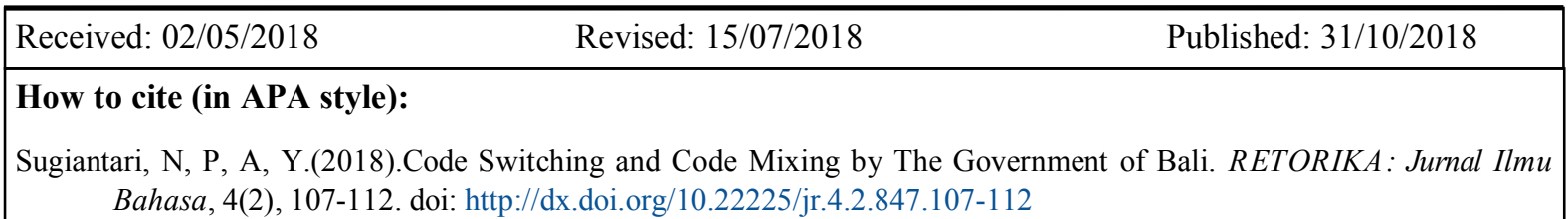

\begin{abstract}
This study examines code-switching and code mixing realized in the interactional activities undertaken by govermental leaders in the Denpasar City of Bali Province, Indonesia. Typically I reveal the language types used by bilingual and multingual governments during code swithing and code mixing events as well as investigating their leading factors. The study was designed using qualitative research method. The results of this study indicate that code mixing dan code-switching undertaken by the leaders in the governmental area of Denpasar city involves 3 types of language, namely Balinese, Indonesian, and English. An element of code mixing filler occurring during interactional process of the leaders is tangible words and phrases. Leading factors to such phenomena of code mixing and code-switching are: language ability, speech topics, speech participants, speech situations, prestige; and creating regional or religious nuances.
\end{abstract}

Keywords: Code mixing; code switching; governmental leader

\section{INTRODUCTION}

Studies on code-switching and code mixing events as strategy of communicating among bilingual and multilingual participants have been a concerned topic recently among linguists. Most of the studies during last two decades revealed how these two elements essentially occur both in separate and in simultaneous way with one another during interaction (Auer, 2005; Mahootian, 2006; Schau, Dellande, \& Gilly, 2007; GardnerChloros, 2009; Chaturvedi, 2015). Even thouh, code-switching and code mixing, infact, have a commonly perceivable creative, artistic, and stylistic functions and that they can be used to emphasize a certain expressive form of linguistic (Jonsson, 2010), existing studies and theories have shown different perspectives. It is true that speakers need to make choices of words when interacting with other people in their communities (Deuchar, 2013). Speakers with a certain and distinct level of ages and education education, however, would have different way of performing for their communication activities. The crucial question is among multilingual and bilingual community, which languages do they prefer to use and switch to when interacting? This question has led to design the present study.

By any change, there are a number of studies carried out to examine code-switching and code-mixing. A study conducted to confirm the maintenance of language boundaries has shown that it is crucial to distinguish and separate between different language mediums (Musk, 2010). Toward exploring communication activities among military officers, a study had been launched particularly to reveal condition of codeswitching activities during the group interaction. It was revealed that both gender and first language have a great influence of code-swithing events (Singh \& Nasir, 2012). Among the speakers in the media, study on code-switching was done and it was discovered that code-switching has both micro and macro functions in movies (Nil \& Paramasivam, 2012). Condition of code-switching among community of a multilingual country was once 
uncovered; it is that code-switching is a highlighted event in a multilingual community (Shay, 2015). Another study has also revealed that bilingual children use a language with fixed syntactic rules, but one that utilises lexemes from any of the source languages (Wilson, Hurst, \& Wigglesworth, 2018). These studies on code-switching and code-mixing have from various perspectives.

Necessarily there would have been a classifying study to types and dominant types of language used during communication of bilingual and multilingual communities. There previous studies have shown the absence of such study and that it still remains an untouched gap. Therefore, the present study seeks to examine the types and the dominant types of language used in multilingual community when making code-switching and code mixing during communicating. This investigation is done from sociolinguistic study approach.

\section{METHOD}

This study was conducted in the capital city of Bali Province, which is in the office of Denpasar City Government. Data were collected through observation and recording techniques. When the process of communication activity took place between the leaders in Denpasar city administration, he was recorded using a handicam. The data collected, then, were analyzed using a qualitative approach, including selecting the required data from among all available data, focusing only on the study of code-switching and code mixing, grouping data by type, and explaining data based on sociolinguistic theory, particularly those of code switching and code mixing. The presentation of data analysis result was done by applying informal method that is by presenting data about the use of language containing code-switching and code mixing descriptively, in the form of words or clauses.

\section{III.DISCUSSION}

\section{Code-switching}

Code-switching is an event that occurs in the form of switching the use of a code to another code (Auer, 2005). Such inguistic pehenomena frequently occur within communication between the leaders in the Denpasar City Government. Based on the results of this research data analysis, the codeswitching realized occurs from three languages, namely Balinese, Indonesian, and English. The most frequent shift is switching from Indonesian to Balinese and vice versa, while those whiche are from Indonesian to English took place rarely. Participants of the speech or participants involved in the code-switching activities are also very diverse. They come from various ranks within the Government of Denpasar, namely the leaders such as the Secretary of Region, Chief of Service, Subdistrict head, and employees within the Government of Denpasar.

In addition, participants of the speech in the event of the transfer of code that occurred in the event of communication were also derived from agencies or institutions outside the Government of Denpasar City and the general public, especially the people of Denpasar. This code change event can also occur in various background situations, both in formal and informal situations. The following is a fragment of sppech that contains codeswitching.

"Yen dados mangkin nika adik-adik ketahui." Pemerintah juga mempunyai banyak pengeluaran yang bisa mengurangi budget kegiatan anda. Kayak kami di Denpasar sekarang menghadapi berbagai persoalan, sampah, kemacetan."

\section{Literal translation:}

'If you can now know, the government also has many expenses that can also reduce your budget activities, such as us in Denpasar now. We are dealth with various problems, such those about garbage, and congestion. Speech in the example above is a speech performed by a leader in the Denpasar City Government.'

\section{Code Mixing}

In addition to the switching code events as discussed above, communication activities of leaders in the Denpasar City Government are also marked by the phenomenon of code mixing. This event seems very often to have occured with a mixture of elements of words and phrases between the three languages, namely Indonesian, Balinese, and English.

Example: Tanggal 26 ini Kabag Kesra punya tanggung jawab niskala.

The sentence in the example above shows the presence of code interfering events. Sentences in the data are BI sentences and in parts there are elements of the Balinese language word (in bold) inserted with a random location in each of the sentence. In the sentence, there is a nipal word inserted at the end of a sentence. In Balinese, the niskala is classified as an adjective and its use is as an element explaining the nouns of responsibility 
so that the two elements become a phrase, namely the noun phrase, i.e. niskala responsibility.

\section{Leading Factors to Code-switching and Code Mixing}

This discussion is about the factors that influence the occurrence of code change and code interference among leaders in the environment of Denpasar City Government. The analysis of this study is also made by informal method, that is by presenting the data of language usage and analyzed descriptively. The following is the analysis presented in a row, i.e. the event of code transfer and code mixing with data marked with an upright letter for BI and italics for Balinese and English.

\section{Factors for Code-switching}

The event of code-switching done by the leaders in Denpasar City Government environment in their communication activity is caused by several factors. These factors are polyglotism, topics, participants, intention of presenting regional nuances, affirming message content, and prestige. Each of these code transfer factors can be described in more detail in the following sections.

\section{Polyglotism}

Observation in this study indicates that the ability of someone in using two tau more languages (polyglotism) is the main factor that causes the occurrence of the event codeswitching on communication activities between leaders in the environment of the Government of Denpasar. What I mean by people who are able to speak in this context are the leaders in the Denpasar City Government able to use more than one kind of language.

\section{Topic of Conversation}

The topics of conversation are also a determining factor to the occurrence of codeswitching on communication activities between leadership of the Government of Denpasar. What I mean by the conversation topic factor is the shift from one topic to another in a conversation (Gardner-Chloros, 2009). The changes on of topics in a speech activity are very common and can occur when a speech is discussed on several topics (Bontly, 2014). The data show that the conversation done by the leaders in the Denpasar City Government is often accompanied by a change of topic conversation. The switching of code caused by the turn of speech topics between the leaders of the Denpasar City government can be seen in the example taken from the data 5 of this study, as follows:

"Tahun mangkin ten sabeh ring hari Hnya. Nah, nunas mase pang sing loba teken sesuwunan, pang sampai jam roras gen endang ba. Suwude to hujan ja bang ba nggih. Ndak masalah nggih. Iraga mase sing dadi loba ken sesuwunan. Pang sampai bin mani sing sabehsabeh.'

Data 5 above is an example of a code transfer event carried out by the leadership of the Denpasar City Government. The topic peech of the conversation is changing.

\section{Participants}

The event of code-switching that occurs in the communication activities of the leaders can also be caused by the participants of the speech (Chaturvedi, 2015). That is, switching the use of language from a language to another language can be caused by the alternation of the spokesman involved in a communication activity being carried out (TAY, 1989). In this research, code-switching caused by turnover of speech participants can be seen in data 3 as follows.

Ten ja calon matie. Camat. Niki nika Pak Camat Densele, kumisne. Coba ngadeg niki Pak Camat, nah tolih niki pang tawange nak lingsir. Niki Camat Densel niki. Bagus niki kumisne. Camat ten mekumise. Camat Denut. Ngadeg Pak Camat, pang tawange niki nak lingsir.

In the above quote of data 3 , there appears to be a transition of language usage by the leaders of the Government of Denpasar who become speakers, from Indonesian to Balinese.

\section{Presenting Regional/Religious Nuances}

The use of language in a communication activity can reflect a goal, such as presenting the nuances of regional or religious speakers. The results of the data analysis of this study indicate that the leadership in the Denpasar City government conducts code-switching in their communication activities in order to express their regional / religious nuances.

"Tetapi, kami sampaikan di awal tentang rencana launching ini akan dilaksanakan pada tanggal 30 Maret ini. Ada usul juga dari Pak Kabag Kerjasama, semua tamu yang masuk itu akan diketiskan tirta."

The quote of the conversation in data 4 above shows the switching code performed by the leadership in the Denpasar City Government. At the beginning of the speech, 
there is the use of the Indonesian language used to communicate with his opponent, namely the ranks of the government of Denpasar. At the end of the sentence, there appears to be a switching code from Indonesian to Balinese. The code is used in the Balinese clause, which is diketiskan tirta. This is also an emphasis of code-mixing and code-switching events among multilingual communities (Auckle \& Barnes, 2011; George, 2014; Mabule, 2015). This clause contains the words, diketiskan 'sprinkled' and tirta 'holy water'. Both of these words refer to a religious activity of Hindus especially in Bali, which is an activity done by sprinkling holy water into a body or body part of a person intended to purify oneself of things that are negative or bad.

\section{Situation of Conversation}

The situation of a conversation can be very diverse and different from one form to another (Deuchar, 2006). Speech can be accompanied by a formal, informal, casual, intimate, tense situation, and the like (Mahootian, 2006). The emergence of situations that accompany such a utterance can be caused by the speech itself or by the deliberate intentions of the speaker. Events of the code change that occurs in leadership communication activities within the Government of Denpasar can also be caused by speech situation factors. As shown by data 3 presented as follows.

Pak Camat yang juga hadir pada kesempatan niki yang tiang hormati. Bersyukur menjadi Camat Densel. Bersyukur jadi camat. Ten ja calon matie. Camat. Niki nika Pak Camat Densele, kumisne. Coba ngadeg niki Pak Camat, nah tolih niki pang tawange nak lingsir. Niki Camat Densel niki. Bagus niki kumisne. Camat ten mekumise. Camat Denut. Ngadeg Pak Camat, pang tawange niki nak lingsir.

The activity of speech on data 3 above shows the transfer of code in the form of the transfer of language usage from Indonesian to Balinese language. The factor that causes the code-switching in the speech is the conversation situation.

\section{Prestige}

Prestige is something inherent in the human self. This aspect is almost owned by everyone and takes place in various places and atmosphere (Shay, 2015). Prestige is expressed in a variety of forms, such as clothing, houses, vehicles, and including language. Like the clothes and vehicles, the language is also considered to have elements that can lead to a prestige like that done by the leaders in the Denpasar City Government environment in their communication activities. The facts are shown by data 6 , that is:

"Nah sekarang how to sell heritage city ini adalah hal yang sangat baik".

In this data sentence 6 it appears that there is a communication activity of a leader in the Denpasar City Government who uses the Indonesian language because his interlocutors are the people who are able to use that language. In the speech, speaker change the code from Indonesian to English, using the phrase "how to sell heritage city". When viewed from the background of his opponent, the use of English clauses by the speakers is actually very contrary because the opponent said in the communication activities. However, it may be noted that the use of the English clause by the speaker is merely aimed at demonstrating his ability to use a foreign language, ie English which the general public perceives as a special ability or prestige in communicating.

\section{Factors for Code Mixing}

Similar to code-switching, code mixing events can occur for several factors. Based on observations in this study, code mixing conducted by the leaders in the Denpasar City Government. The code mixing factors are the limitations of meaning affirmation.

\section{Limitation of Meaning}

The meaning of a word of a language may not be precisely expressed in another language (Siregar, Bahri, \& Sanjaya, 2014). This can happen because of the different linguistic, social, and cultural backgrounds that exist between the two languages. Limitation of meaning as mentioned appears in the leadership speech activity in the Denpasar City Government, so they mixed the code. This is shown by data 7 .

\section{"Tanggal 26 ini Kabag Kesra punya tanggung jawab niskala”.}

In this sentence it appears that the language used is Indonesian and a Balinese language vocabulary is inserted, ie niskala. Conceptually, the word niskala seems difficult to explain both in the Balinese language itself and in other languages such as Indonesian. Thus, the speaker in the communication activity cannot avoid the full use of the word niskala in the Indonesian sentence. Limitations of meaning that occurs in the form of code 
mixing by leaders in the environment of the Government of Denpasar City can also be found on the use of the language of Bali. This can be seen in sentence b data 13 .

\section{"Meriki tiang nikaine mangkin berarti niki daerah bahaya."}

Language used in the sentence is Balinese but there is a code mixing event, where the speakers insert an Indonesian phrase i.e. the dareah bahaya 'dangerous area'. The equivalent of leksikon daerah bahya, especially daerah 'area' or 'region' seems difficult to put forward in the Balinese language so that the the speaker maintains the use of the Indonesian term for region in his speech.

\section{Unitentionality}

Code mixing events can also be caused by factors of incompetence. What is meant by chance is an accidental speaker using an element of another language so that other language elements spontaneously appear in his speech. Code mixing events caused by accidental factors can also be found in conversation events in communication conducted by leaders in the Denpasar City Government. It is very easy to find in their speech as in the sentence in the data 11 below.

\section{"Itu yang kami stressing."}

The word stressing in the sentence above is an English vocabulary that has been very commonly used by people who are involved in the formal sector, especially in government institutions such as the Government of Denpasar. People who work as officials in the field of government, such as leaders in the government of Denpasar City generally already know the word stressing, including its meaning so that in their various communication activities, unwittingly the word is tucked into their speech.

\section{Prestige}

Prestige can lead to mixing of codes in a communication activity. This factor can occur especially when the elements that fill the code mixing element come from a foreign language, such as English. As the data obtained from the communication activities of leaders in the Denpasar City Government, code mixing events that they do caused by the prestige factor that is the use of elements of English in their communication activities.

"Itu yang kami stressing".

The use of English words in these sentences is stressing, whose meaning can also be found in the Indonesian language. The meaning of the word stressing in the Indonesian language is emphasis; however, as the speaker, in this case the leader in the Denpasar City Government still uses the words in Indonesian sentences, seeming solely to give the impression of prestige on his communication activities.

\section{IV.CONCLUSION}

Act of code-switching and code mixing that occurs in the communication activities of leaders in the Denpasar City Government environment shows a pattern. The pattern is the use of 3 types of language, namely the language of Bali, Indonesian, and English. Code-switching between the three types of language can occur from Balinese to Indonesian or vice versa. Also encountered the transfer of code from Indonesian to English but the code-switching is very rare and does not happen otherwise, ie from English to Indonesian. Then, the event code mixing that occurs in the communication activities undertaken by the leaders in the neighborhood of the City Government in Denpasar can involve 3 types of language, namely the language of Bali, Indonesian, and English. Code mixing with these types of languages is in the form of use or insertion of Indonesian elements in the use of the Balinese language, the use of Balinese language elements in the use of the Indonesian language, the use or insertion of elements of English in the use of the Indonesian language, elements of English in the use of Balinese.

Leading factors to code-switching events in communication activities carried out by the leaders of the Municipal Government in Denpasar are due to: a) language ability, b) topics of conversation, c) participants, d) purpose of bringing regional or religious nuances, e) situation, and f) prestige. In addition, leading factors to code mixing in communication activities conducted by the leaders in the neighborhood of Government in Denpasar City are a) the limitations of meaning, b) unintentionality, and c) the prestige of the participants.

This study is limited to description of language types and the factors of codeswitching and code-mixing events. Social reasons and linguistic level reasons would be further topic of study to be conducted.

\section{ACKNOWLEDGMENT}


The authors would like to thank my lecturers for having provided opportunity and having guided the author in accomplishing this article to be published. I would also like to thank the Editorial Team of Retorika Journal of Warmadewa University for the guidance provided to the author so that this article is published

\section{REFERENCES}

-, S., Siregar, M., Bahri, S., \& Sanjaya, D. (2014). Code Switching and Code Mixing in Indonesia: Study in Sociolinguistics? English Language and Literature Studies, 4(1), 7792.

Auckle, T., \& Barnes, L. (2011). Code-switching, language mixing and fused lects: Emerging trends in multilingual Mauritius. Language Matters, 42(1), 104-125.

Auer, P. (2005). A postscript: Code-switching and social identity. Journal of Pragmatics, 37(3 SPEC.ISS.), 403-410.

Bontly, T. D. (2014). Conversational Implicature and the Referential Use of Descriptions, 125 (1), 1-25.

Chaturvedi, S. (2015). A Sociolinguistic Study of Linguistic Variation and Code Matrix In Kanpur. Procedia - Social and Behavioral Sciences, 192, 107-115.

Deuchar, M. (2006). Welsh-English code-switching and the Matrix Language Frame model. Lingua, 116(11), 1986-2011.

Deuchar, M. (2013). Code Switching, (2), 508-511.

Gardner-Chloros, P. (2009). Code-switching. CodeSwitching, 39, 1-242.

George, R. (2014). Mark Sebba, Shahrzad Mahootian, \&amp; Carla Jonsson (eds.), Language mixing and code-switching in writing: Approaches to mixed-language written discourse. New York: Routledge, 2012. Pp. viii, 275. Hb. \$130. Language in Society, 43(1), 125-126.

Jonsson, C. (2010). Functions of code-switching in bilingual theater: An analysis of three Chicano plays. Journal of Pragmatics, 42(5), 1296-1310.

Mabule, D. R. (2015). What is this? Is It Code Switching, Code Mixing or Language Alternating? Journal of Educational and Social Research, 5(1), 339-350. https:// doi.org/10.5901/jesr.2015.v5n1p339

Mahootian, S. (2006). Code-switching and mixing. Encyclopedia of Language \& Linguistics , 511-527.
Musk, N. (2010). Code-switching and code-mixing in Welsh bilinguals' talk: Confirming or refuting the maintenance of language boundaries? Language, Culture and Curriculum, 23(3), 179-197.

Nil, Z. M., \& Paramasivam, S. (2012). CodeSwitching in Gol \&amp; Gincu. Procedia Social and Behavioral Sciences, 66, 169175.

Schau, H. J., Dellande, S., \& Gilly, M. C. (2007). The impact of code switching on service encounters. Journal of Retailing, 83(1), 6578 .

Shay, O. (2015). To Switch or Not to Switch: Codeswitching in a Multilingual Country. Procedia - Social and Behavioral Sciences, 209(July), 462-469.

Singh, S. K. S., \& Nasir, A. Q. binti A. (2012). Code-Switching among Military Cadet Officers During Group Interaction. Procedia - Social and Behavioral Sciences, 66, 64-75.

TAY, M. W. J. (1989). Code switching and code mixing as a communicative strategy in multilingual discourse. World Englishes, 8 (3), 407-417.

Wilson, A., Hurst, P., \& Wigglesworth, G. (2018). Language Practices of Indigenous Children and Youth. 